Note

\title{
ALTERNATIVE METHOD FOR VOLUMETRIC CORE REMOVAL IN HARDSETTING SOILS
}

\author{
Herdjania Veras de Lima ${ }^{1}$; Álvaro Pires da Silva ${ }^{2 *}$; Sílvia Imhoff ${ }^{3}$; Afrânio Ferreira Neves \\ Junior $^{4}$ \\ ${ }^{l}$ UFC - Depto. de Ciência do Solo, Av. Mister Hull s/n, Campus do Pici, Bloco 807 - 60455-760 - Fortaleza - \\ CE - Brasil. \\ ${ }^{2}$ USP/ESALQ - Depto. de Solos e Nutrição de Plantas, Av. Pádua Dias, 11, C.P. 9 - 13418-900 - Piracicaba, SP - \\ Brasil. \\ ${ }^{3}$ Universidad Nacional del Litoral, Av. P. Kreder 2805, C.P. 3080. Esperanza, SF - Argentina. \\ ${ }^{4}$ USP/ESALQ - Programa de Pós-Graduação em Solo e Nutrição de Plantas. \\ *Corresponding author < apisilva@esalq.usp.br>
}

\begin{abstract}
Due to the narrow window of ideal moisture conditions required for collecting undisturbed soil samples from hardsetting horizons in the field, this study compared the efficiency of an alternative method of soil core removal in the laboratory with that of the traditional field method by using measurements of soil bulk density data $\left(\mathrm{D}_{\mathrm{b}}\right)$. In a first sampling, cylinders were removed with a soil sampler in the field. In a second sampling, large soil blocks were removed with Kubiena-type zinc (brass) boxes in the field. Volumetric core cylinder samples were removed from these blocks in the laboratory with a manual hydraulic pump. There were no differences between the $\mathrm{D}_{\mathrm{b}}$ values determined from the laboratory and the field coring method. The laboratory method was considered more efficient than the field method because it allowed reductions in the errors made by operators in the field, and those caused by differences in soil water content. The laboratory method allows sampling in hardsetting horizons throughout the year, and collecting soil core samples under conditions of controlled moisture and applied force.
\end{abstract}

Key words: soil sampler, undisturbed samples, soil bulk density

\section{MÉTODO ALTERNATIVO PARA A RETIRADA DE ANÉIS VOLUMÉTRICOS EM SOLOS COESOS}

\begin{abstract}
RESUMO: Devido à grande dificuldade em se determinar à umidade ideal para a coleta de amostras com estrutura indeformada nos solos com horizontes coesos, este trabalho testou a hipótese que a utilização de um método alternativo para retirada de anéis volumétricos em laboratório não influenciaria a qualidade das amostras e, portanto, os resultados obtidos a partir delas. O objetivo deste trabalho foi comparar a eficiência de um método alternativo de retirada de anéis volumétricos no laboratório com o método tradicional de retirada no campo utilizando, para isso, os dados de densidade do solo (Ds). Foram feitas duas amostragens de solo: (i) na primeira foram retirados anéis com amostrador de solo e, (ii) na segunda foram retirados blocos de solo com caixas de zinco (latão) do tipo Kubiena. Esses blocos foram utilizados para retirar anéis volumétricos em laboratório com ajuda de uma bomba hidráulica manual. Não houve diferenças significativas entre os valores de $\mathrm{Db}$ obtidos com ambos os métodos: de laboratório e de campo. O método alternativo de laboratório é mais eficiente que o de campo, já que permite minimizar os erros provenientes do operador na amostragem de campo e aqueles causados por diferenças do conteúdo de água no solo. O método proposto permite coletar amostras nos horizontes coesos em qualquer época do ano e obter os anéis volumétricos em condições controladas de umidade e força aplicada.

Palavras-chave: amostrador de solo, amostras indeformadas, densidade do solo
\end{abstract}

\section{INTRODUCTION}

To study of hardsetting soils, preliminary identification is made qualitatively in the field, and the observation of a dry soil profile is fundamental to characterize the absence of structure and to test the behavior of small fragments of the dry soil when immersed in water. However, the use of quantitative parameters to test the cohesion of these soils is extremely important in characterizing their behavior. Soil bulk density, porosity, pore size distribution, and penetration resistance are the main soil physical properties measured to identify and quantify hardsetting horizons (Souza et al., 2001; Franzmeier \& Chartres, 1996). Measurements of these soil properties are usually done on undisturbed soil samples. Therefore, precision of assessments depends directly on the quality of soil samples. 
Efficient determination of soil bulk density $\left(D_{b}\right)$ by the core method depends on soil compressibility and shattering, which are affected by sample size and soil water content (Chan, 2002). The ideal moisture content for undisturbed sample collection in the field (i.e. to prevent soil compression within the core) is near field capacity ( $\Psi=-10 \mathrm{kPa}$ ) (Chan, 2002). Lima et al. (2005) showed that in hardsetting horizons with sandy clay loam texture (28\% clay), and soil moisture content close to 0.13 $\mathrm{cm}^{3} \mathrm{~cm}^{-3}(\Psi=-50 \mathrm{kPa})$, the soil's high mechanical resistance $(>3 \mathrm{MPa})$ hinders the collection of undisturbed samples.

Areas of the Coastal Tablelands (where soils with hardsetting horizons occur), experience long periods of water shortage during the dry season and excess water during the rainy season (Rezende et al., 2002). Therefore, most soils pass from an excessively wet stage in the rainy season to an extremely dry stage in the drought (Cintra et al., 1997). Because they present hard to extremely hard consistency when dry and immediately soften when moistened (Jacomine, 1996). Soils with hardsetting horizons present a narrow range of ideal soil moisture for collection of undisturbed samples in the field. Therefore, sample collection during the dry season becomes extremely difficult because of the high penetration resistance of the hardsetting horizons, which generally results in samples unsuitable for analysis (Ribeiro, 2001). On the other hand, during the wet season, the soil can be easily compressed inside the core, and that also impacts sample quality.

Because it is difficult to collect volumetric cylinders in the field without altering soil structure, this study tested the hypothesis that an alternative method to remove volumetric cylinders under laboratory conditions would not diminish the soil sample quality. Therefore, the objective of this study was to compare the efficiency of an alternative method of soil core removal in the laboratory with that of the traditional field method by using measurements of soil bulk density.

\section{MATERIAL AND METHODS}

This study was carried out in the county of Pacajus, Ceará, Brazil ( $4^{\circ} 10^{\prime} \mathrm{S}$ and $\left.38^{\circ} 27^{\prime} \mathrm{W}\right)$. According to the Köppen classification, the climate in the region is Aw, hot with a rainy summer and dry winter, mean daily temperature in the coldest month above $18^{\circ} \mathrm{C}$, and 800 to $1100 \mathrm{~mm}$ mean annual rainfall (Jacomine et al., 1973). Soil samples were obtained from a hardsetting Arenic Kandiustult, with particle size distribution of $290 \mathrm{~g} \mathrm{~kg}^{-1}$ clay, $40 \mathrm{~g} \mathrm{~kg}^{-1}$ silt and $670 \mathrm{~g} \mathrm{~kg}^{-1}$ sand. The hardsetting horizon was found at a depth of $0.97 \mathrm{~m}$ and the profile had to be exposed for sample collection. Samplings were carried out either on dry days during the rainy season, or shortly following the rainy season, when soil moisture was $\mathrm{H}^{\prime \prime} 0.12 \mathrm{~g} \mathrm{~g}^{-1}$.
In dry days, rainy season, ten $4.0 \mathrm{~cm}$ high $\times 2.4$ $\mathrm{cm}$ diameter soil cylinders were collected using a soil sampler which consisted of an outer holder cylinder (where the cylinder was inserted) and a $22 \mathrm{~cm}$ long insertion handle (Figure 1). The sampler was inserted into the soil by hitting it with a rubber mallet until the cylinder was completely filled. Next, the cylinder was removed from the sampler, and excess, protruding soil was cut off with a knife so that the sample volume corresponded to the cylinder volume. Soil bulk density was determined in laboratory according to the core method proposed by Grossman \& Reinsch (2002).

Kubiena type boxes $(22 \mathrm{~cm}$ long $\times 14 \mathrm{~cm}$ wide $\times$ $10 \mathrm{~cm}$ tall) (Figure 2) were used to collect soil blocks without disturbing soil structure shortly following the rainy season. The boxes were made from zinc metal sheets, $0.25 \mathrm{~mm}$ thick, bearing top and bottom lids. Blocks, dimensioned identically to the zinc boxes, were sculpted out of the profile wall with a knife. After sculpting the soil block, the zinc box was carefully inserted (Figure 3) and removed together with the soil block using a knife. Excess soil was removed and the box closed with the lids. This method of collection ensured that the soil sample arrived at the laboratory bearing the physical characteristics identical to that in the field, ensuring its quality.

Zinc lids were then removed and a permeable fabric was attached to one side of the box with an elastic band. The soil blocks were placed on a tray and gradually moistened from the bottom by adding thin layers of water $( \pm 1 \mathrm{~cm})$ until the upper part of the sample was wet. The soil moisture at this moment was $\approx 0.14 \mathrm{~g} \mathrm{~g}^{-1}$. Next, the soil block was placed over a steel stand used as a counterweight during cylinder removal. Using a hydraulic press (SKAY- SY 412) coupled to a manual hydraulic pump (SKAY - SH 304, maximum pressure $700 \mathrm{kgf}$ $\mathrm{cm}^{-2}$ ) a metal grid with sharp edges was inserted into the block (Figure 4a), dividing it into ten, $29 \mathrm{~cm}^{2}$ blocks, so

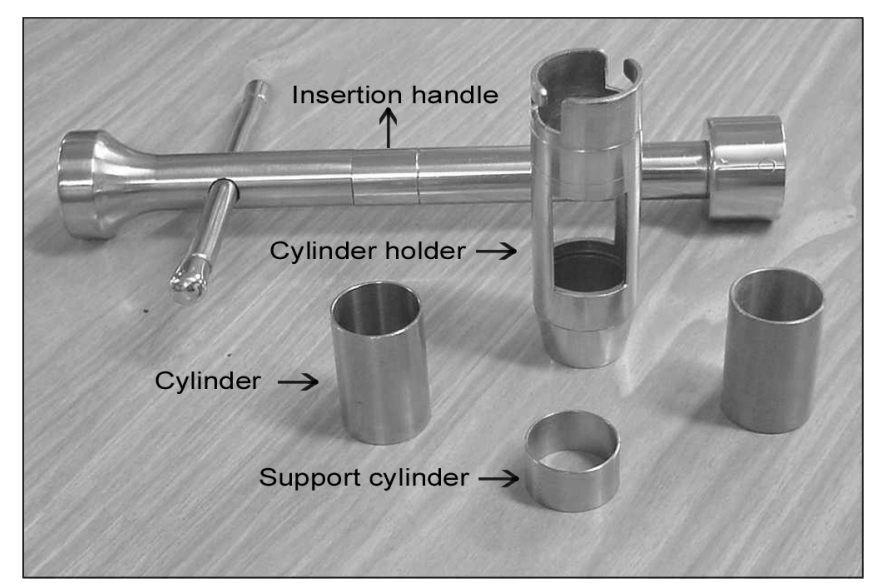

Figure 1 - Soil sampler used in the field to collect undisturbed samples. 
that the removal of a cylindrical volume would not disturb the rest of the sample. The internal and external walls of the grid were coated with solid, white Vaseline, reducing the metal-soil friction and to cause the least disturbance possible during sampling.

After inserting the grid, cylinders $(\mathrm{n}=10)$ identical to those used in the field were inserted into the soil block. The internal and external walls of each core were coated with solid, white Vaseline, to reduce friction while inserting the cylinder into the soil, preventing soil compaction. A support cylinder of the same diameter, aver-
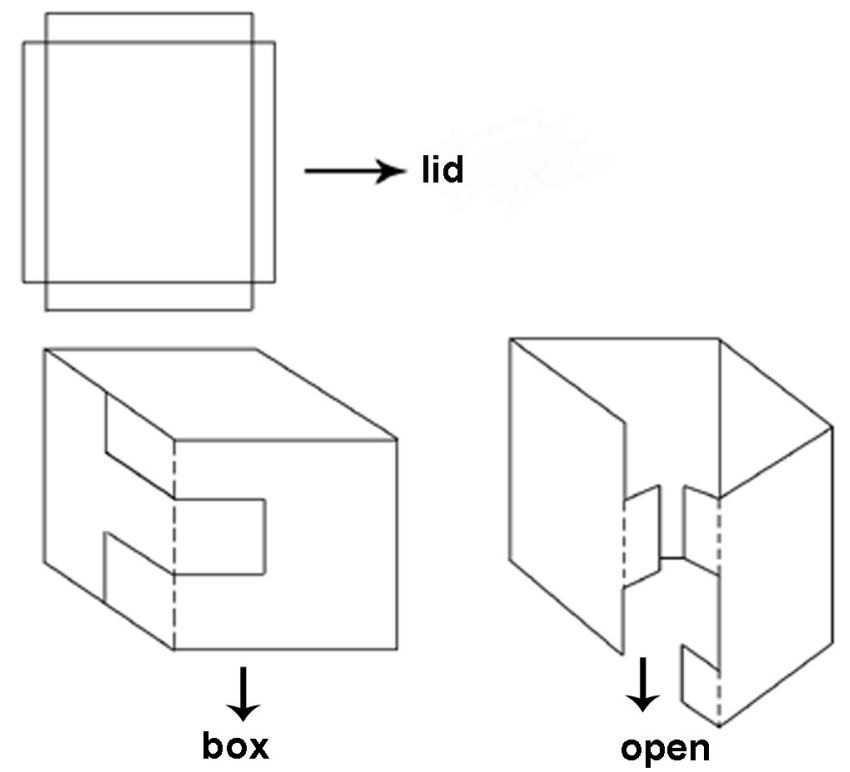

Figure 2 - Kubiena-type zinc box used to collect undisturbed samples in the field. Adapted from Mermut (1992). age height $1.5 \mathrm{~cm}$, was placed on top of the sample cylinder to prevent compaction at the upper end of the sample. The two cylinders were inserted together and the support cylinder was removed shortly after sampling (Figure $4 \mathrm{~b}$ ). The time required to insert the cylinder into the soil was approximately one minute. After inserting all the cylinders, the zinc box was opened (Figure 4c) and the samples were carefully removed. Next the soil samples were oven-dried at $105^{\circ} \mathrm{C}$ for $24 \mathrm{~h}$, and the soil bulk density $\left(D_{b}\right)$ was determined according to the method of Grossman \& Reinsch (2002).

\section{Soil Surface}

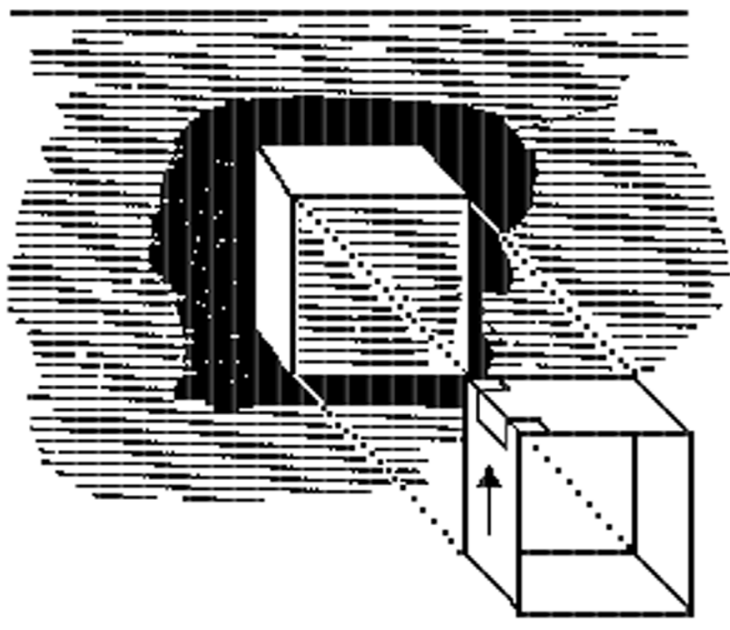

Figure 3 - Illustration showing the fit of the Kubiena-type zinc box in the soil. Adapted from Mermut (1992).
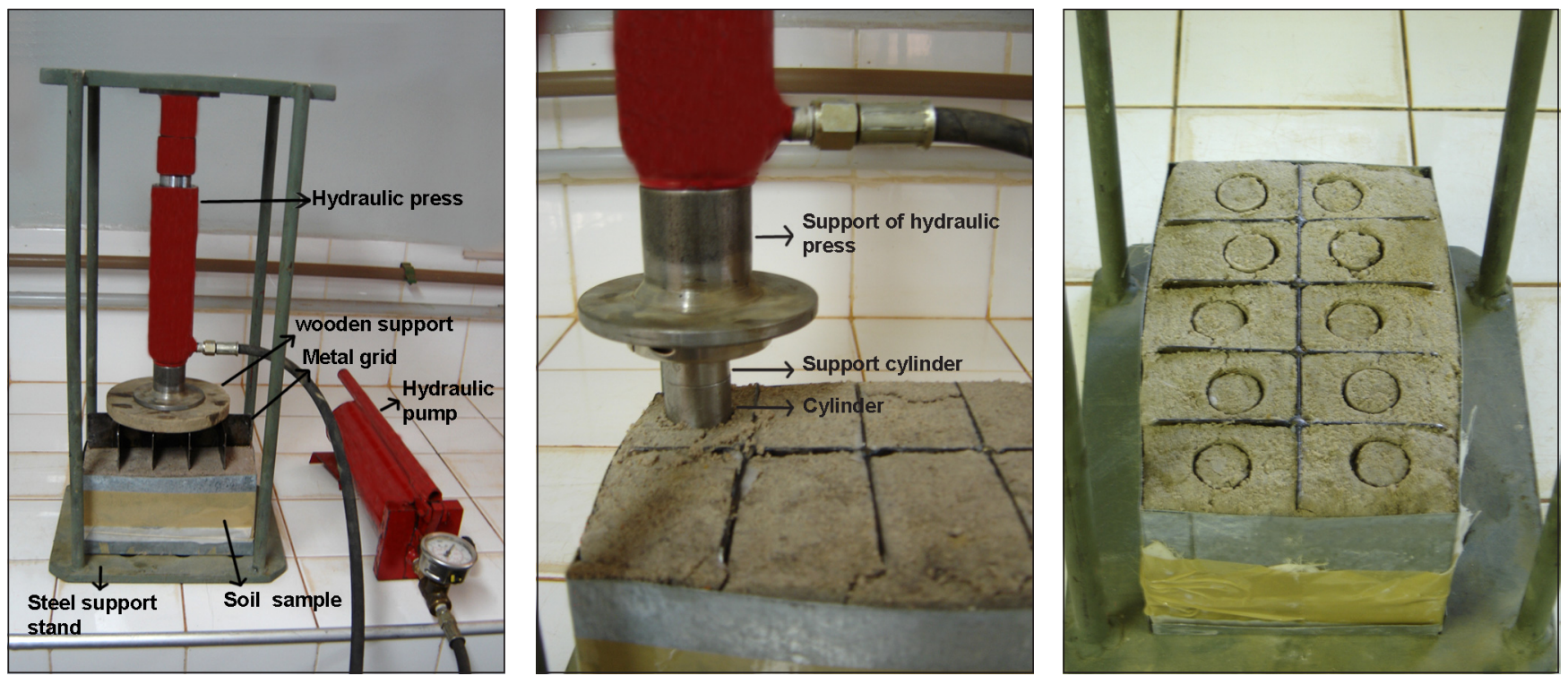

Figure 4 - Photograph showing the insertion of the dividing grid in the soil sample (a), detail of the volumetric cylinder insertion (b) and soil sample after inserting all the volumetric cylinders (c). Steel support stand dimensions: top and bottom $(25 \mathrm{~cm}$ length, $30 \mathrm{~cm}$ wide, $1 \mathrm{~cm}$ thickness), height (bottom-top): $60 \mathrm{~cm}$. 
Table 1 - Statistical moments and $t$ test results for the volumetric core removal method in the field and in the laboratory.

\begin{tabular}{lcccccc}
\hline Method & $\mathrm{N}$ & $\mathrm{Db}$ & Standard deviation & Coefficient of variation & $\mathrm{T}$ & $\mathrm{P}>\mathrm{t}$ \\
\hline & & $\mathrm{g} \mathrm{cm}^{-3}$ & & $\%$ & & \\
Field & 10 & 1.71 & 0.038 & 2.2 & -1.331 & 0.1997 \\
Laboratory & 10 & 1.69 & 0.033 & 2.0 & \\
\hline
\end{tabular}

Shapiro-Wilk statistic (SAS Institute, 1991) was used to test the $\mathrm{D}_{\mathrm{b}}$ normality. Variance analysis (ANOVA) and $t$ test were used to compare the soil bulk density data (SAS Institute, 1991).

\section{RESULTS AND DISCUSSION}

The frequency distribution of the soil bulk density $\left(\mathrm{D}_{\mathrm{b}}\right)$ values was normal according to the ShapiroWilk test; $\mathrm{W}=0.912$ and $\mathrm{p}<\mathrm{W}=0.284$ for the field method and $\mathrm{W}=0.894$ and $\mathrm{p}<\mathrm{W}=0.177$ for the laboratory method. The mean value of $\mathrm{D}_{b}$ and the coefficient of variation $(\mathrm{CV})$ for each of the sampling methods are shown in Table 1. The $t$ test showed no difference between the means indicating that the $\mathrm{D}_{\mathrm{b}}$ values were not affected by sampling method (Table 1). Similar minimum and maximum $\mathrm{D}_{\mathrm{b}}$ values for in the field (1.65 to $1.76 \mathrm{~g} \mathrm{~cm} \mathrm{~cm}^{-3}$ ) and the laboratory (1.61 to $1.73 \mathrm{~g} \mathrm{~cm}^{-3}$ ) methods were recorded. Values determined in laboratory and field in this study are within this $\mathrm{D}_{\mathrm{b}}$ ranges routinely used as a physical parameter to identify and quantify hardsetting horizons -1.5 to $1.8 \mathrm{~g} \mathrm{~cm}^{-3}$ (Araujo Filho et al., 2001).

Results herein reported also agreed with those obtained by Cintra \& Libardi (1998). These authors used the Uhland soil sampler to measure bulk density. The mean $\mathrm{Db}$ value $\left(1.72 \mathrm{~g} \mathrm{~cm}^{-3}\right)$ of the hardsetting horizon was similar to that reported here. Techniques used with different types of samplers can influence the $D_{b}$ values (Folegatti et al. 2001). In addition, differences in the $D_{b}$ values can be caused by the method used to determine $\mathrm{D}_{\mathrm{b}}$. In general, the volumetric core method is considered better than the clod method for $\mathrm{D}_{\mathrm{b}}$ assessment because it presents lower coefficient of variation (Vanremortel \& Shields, 1993; Silva et al., 2000). However, many factors can influence $\mathrm{D}_{\mathrm{b}}$ and be considerable sources of error even when common methods are used (Kulmatishi \& Beard, 2004).

The lack of standardization of some basic factors, such as sampler size and shape, force and velocity applied at insertion, sample removal speed, and soil moisture status at sampling, may be sources of errors influencing differences in reported $D_{b}$ values. Because it is impossible to establish standards at each stage of sampling in the field these errors are difficult to quantify, but have to be considered great importance especially when $\mathrm{D}_{\mathrm{b}}$ values are compared. Therefore, developing alterna- tive methods that allow reduction or elimination of sampling errors is of extreme importance to correctly compare $\mathrm{Db}$ values.

The proposed laboratory method seems to combine both conditions: reduction in method-dependent errors because cylinders are used, and in errors related to the type of sampler and sampling techniques in the field since there is no need of a sampler. This is very important, especially when results are generated by laboratories that target the fulfillment of high quality standards. An additional advantage of the method is that standards can be set for each of activities carried out (field or laboratory), so that good quality soil samples can be used to generate more reliable results.

In this study, the volumetric core removal method in the laboratory was as efficient as the field method, accepted as the traditional method. However, the first method can be considered better since it allows sample collection in the field at any time. Further advantages include reduced physical effort and sampling time. However, the proposed method is advantageous for sample collection from subsurface layers such as hardsetting horizons. Nonetheless, the efficiency of the laboratory method in obtaining good soil samples from superficial horizon need to be tested. Additional research is needed to determine the suitability of the laboratory method in evaluating other soil physical properties.

\section{REFERENCES}

ARAUJO FILHO, J.C.; CARVALHO, A.; SILVA, F.B.R. Investigações preliminares sobre a pedogênese de horizontes coesos em solos dos tabuleiros costeiros do Nordeste do Brasil. In: WORKSHOP COESÃO EM SOLOS DOS TABULEIROS COSTEIROS, Aracaju, 2001. Proceedings. Aracaju: Embrapa Tabuleiros Costeiros, 2001. p.123-142.

CHAN, K.Y. Bulk density. In: LAL, R., (Ed.) Encyclopedia of soil science. New York: Marcel Dekker, 2002. p.128-130.

CINTRA, F.L.D.; LIBARDI, P.L. Caracterização física de uma classe de solo do ecossistema do Tabuleiro Costeiro. Scientia Agricola, v.55, p.367-378, 1998.

CINTRA, F.L.D.; LIBARDI, P.L.; SILVA, A.P. Tabuleiros Costeiros do Nordeste do Brasil: Uma análise dos efeitos do regime hídrico e da presença de camadas coesas nos solos. Boletim Informativo da Sociedade Brasileira de Ciência do Solo, v.22, p.77-80, 1997.

FOLEGATTI, M.V.; BRASIL, R.P.C.; BLANCO, F.F. Sampling equipment for soil bulk density determination tested in a Kandiudasfic eutrodox and a typic Hapludox. Scientia Agricola, v.58, p.833-838, 2001.

FRANZMEIER, D.P.; CHARTRES, C.J. Hardsetting soil in southeast Australia: landscape and profile processes. Soil Science Society of America Journal, v.60, 1178-1187, 1996.

GROSSMAN, R.B.; REINSCH, T.G. Bulk density and linear extensibility. In: DICK, W.A. (Ed.) Methods of soil analysis: Physical methods. Madison: SSSA, 2002. p.201-228. 
JACOMINE, P.K.T. Distribuição geográfica, característica e classificação dos solos coesos dos Tabuleiros Costeiros. In: REUNIÃO TÉCNICA SOBRE SOLOS COESOS DOS TABULEIROS COSTEIROS, Aracaju, 1996. Aracaju: EMBRAPA, CPATC; CNPMF; EAUFBA; IGUFBA, 1996. p.13-26.

JACOMINE, P.K.T.; ALMEIDA, J.C.; MEDEIROS, L.A.R. Levantamento exploratório - reconhecimento de solos do Estado do Ceará. Recife: SUDENE, 1973. 830p.

KULMATISHI, A.; BEARD, K.H. Reducing sampler error in soil research. Soil Biology \& Biochemistry, v.36, p.383-385, 2004.

LIMA, H.V.; SILVA, A.P.; ROMERO, R.E.; JACOMINE, P.T.K. Comportamento físico de um Argissolo Acinzentado Coeso no Estado do Ceará. Revista Brasileira de Ciência do Solo, v.29, p.33-40, 2005.

MERMUT, A.R. Introduction to soil micromorphology. Saskatoon: University of Saskatchewan, Department of Soil Science, 1992. 115p.

REZENDE, J.O.; MAGALHÃES, A.F.J.; SHIBATA, R.T.; ROCHA, E.S.; FERNANDES, J.C.; BRANDÃO, F.J.C.; REZENDE, V.J.R.P. Citricultura nos solos coesos dos Tabuleiros Costeiros: análise e sugestões. Salvador: SEAGRI-SPA, 2002. 94p.

RIBEIRO, M.R. Características morfológicas dos horizontes coesos dos solos dos Tabuleiros Costeiros. In: WORKSHOP COESÃO EM SOLOS DOS TABUlEIROS COSTEIROS, Aracaju, 2001. Proceedings. Aracaju: Embrapa Tabuleiros Costeiros, 2001. p.161-168.
SAS Institute. SAS/STAT procedure guide for personal computers. Version 8.3. Cary: SAS Institute, 1991.

SILVA, V.R.; REINERT, D.J.; REICHERT, J.M. Comparação entre os métodos do cilindro e do torrão na determinação da porosidade e da densidade do solo. Ciência Rural, v.30, p.1065-1068, 2000.

SOUZA, L.S.; SOUZA, L.D.; CALDAS, R.C. Identificação da coesão com base em atributos físicos convencionais em solos dos Tabuleiros Costeiros. In: WORKSHOP COESÃO EM SOLOS DOS TABULEIROS COSTEIROS, Aracaju, 2001. Proceedings. Aracaju: Embrapa Tabuleiros Costeiros, 2001. p.169-190.

VANREMORTEL, R.D.; SHIELDS, D.A. Comparison of clod and core methods for determination of soil bulk density. Communications in Soil Science and Plant Analysis, v.24, p.2517-2528, 1993.

Received February 18, 2005

Accepted August 08, 2005 